Przegląd Prawa Konstytucyjnego

----ISSN 2082-1212-----

DOI 10.15804/ppk.2018.03.11

-----Nr $3(43) / 2018-----$

\title{
Wspomnienie o Panu Profesorze Bogusławie Banaszaku
}

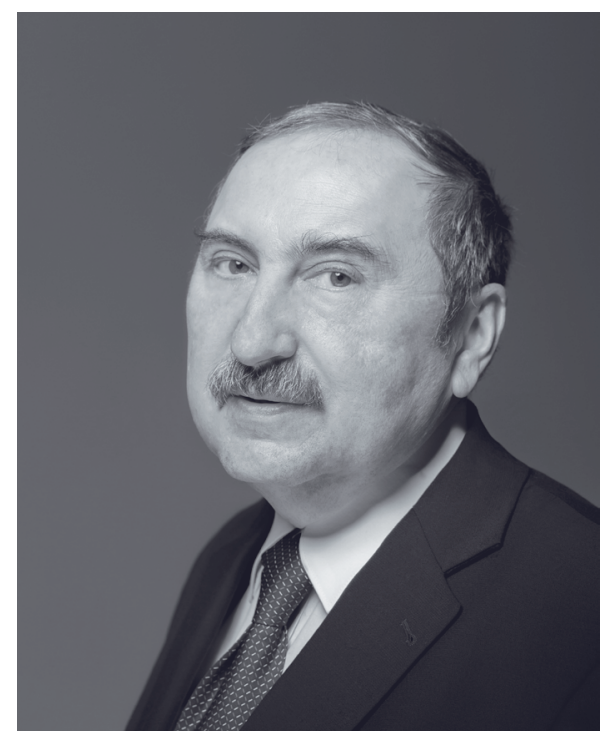

W kilku krótkich słowach czy akapitach nie jest możliwe przedstawienie osoby Pana Profesora Bogusława Banaszaka, który odszedł do wieczności na początku 2018 r. Jednak w tych kilku zdaniach może uda się chociaż przybliżyć Jego postać.

Z urodzenia wrocławian (3 luty 1955 r.), tam też spędził prawie całe swoje życie, kończąc III Liceum Ogólnokształcące im. A. Mickiewicza. Po ukończeniu szkoły średniej, z wysokimi wynikami zresztą, studiował prawo na ówczesnym Wydziale Prawa i Administracji Uniwersytetu Wrocławskiego. Początkiem kariery naukowej było już ukończenie studiów z wyróżnieniem. Takie wyniki pozwoliły Mu ubiegać się o zatrudnienie na uczelni w charakterze pracownika naukowo-dydaktycznego aż do 2014 r. W tym czasie obronił rozprawę doktorską (1983 r.), po czym został zatrudniony na stanowisko adiunkta. 
Po kilku latach intensywnej pracy naukowej i dydaktycznej uzyskał stopień doktora habilitowanego (1991 r.), a następnie został zatrudniony na stanowisku profesora nadzwyczajnego Uniwersytetu Wrocławskiego. Tytuł profesora nauk prawnych otrzymał w 1998 r., a od 1999 r. pracował na stanowisku profesora zwyczajnego Uniwersytetu Wrocławskiego. Od 2002 r. do 2014 r. kierował Katedrą Praw Konstytucyjnego na tym Wydziale.

Jako osoba aktywna i lubiąca się dzielić swoją wiedzą i doświadczeniem z jak najszerszym gronem studentów w latach 1995-2005 pracował podjął zatrudnienie w Wyższej Szkole Zarządzania i Marketingu we Wrocławiu. Tam też umiejętności organizatorskie Profesora pozwoliły Mu pełnić funkcję prorektora. Dodatkowo od 2005 r. współpracował z Państwową Wyższą Szkołą Zawodową im. Witelona w Legnicy, a także w latach 1998-2008 kierował Katedrą Polskiego Prawa Publicznego na Wydziale Prawa Europejskiego Uniwersytetu Viadrina (Frankfurt nad Odrą).

Profesor Banaszak lubił kreować i tworzyć, te cechy spowodowały, ze rozpoczął jako Pełnomocnik Rektora Uniwersytetu Zielonogórskiego współpracę z Uniwersytetem Zielonogórskim w celu utworzenia Wydziału Prawa i Administracji na tamtejszym uniwersytecie. Szybkość i skuteczność w działaniu pozwoliły zakończyć powierzone Mu zadanie z sukcesem, ponieważ już 1 października 2014 r. wydział zainaugurował swoją działalność. Od tego momentu Profesor Banaszak swoją karierę naukową związał z Wydziałem Prawa i Administracji Uniwersytetu Zielonogórskiego, gdzie pełnił funkcję Dziekana tegoż wydziału oraz kierował Katedrą Prawa Konstytucyjnego.

Pan Profesor Banaszak był niezwykle płodnym naukowcem, co spowodował, że napisał ponad 300 prac naukowych o różnym charakterze, ponieważ wśród z nich znajdziemy monografie, podręczniki, komentarze, studia, a przede wszystkim artykuły. Spora część z Jego publikacji została wydana za granicą. Jako, że znał biegle kilka języków obcych, wykorzystał i tą wiedzę na przetłumaczenie książek i artykułów prawniczych.

Lubił podróżować i zwiedzać, a piękno świata pokazywał swojemu wnukowi. Ponadto łatwość i nawiązywaniu kontaktów z ludźmi i Jego otwartość spowodowała, że miał przyjaciół rozsianych po całym świecie. Cechy te spowodowały, że wielokrotnie był zapraszany do wygłoszenia gościnnych wykładów na zagranicznych uniwersytetach. Aktywnie uczestniczył również w międzynarodowych konferencjach naukowych. 
Ponadto Profesor Banaszak udzielał się w kilkunastu kolegiach redakcyjnych czasopism naukowych oraz kilkunastu towarzystwach naukowych, w tym wielu zagranicznych.

Pan Profesor Bogusław Banaszak był cenionym i lubianym nauczycielem akademickim. Studenci poznawali Profesora już na pierwszym roku studiów na wykładzie z prawa konstytucyjnego. Sala, w której odbywał się wykład z Profesorem zawsze była pełna, potrafił zainteresować i zaciekawić studentów przedmiotem zajęć, w szczególności poprzez opowiadanie licznych anegdot, które dodatkowo podkreślały i uwydatniały poszczególne prawa i wolności zawarte w Konstytucji RP. Sympatia i szczery uśmiech kierowany w stronę studentów spowodowały, że niejednokrotnie został uznany za najsympatyczniejszego wykładowcę.

Młodych ludzi żądnych wiedzy i chęci własnego rozwoju wspierał zawsze i na każdym etapie ich kariery, nie tylko jako mentor i przewodnik, ale także jako doradca i przyjaciel. Bezsprzecznie świadczą o tym liczne promocje doktorskie i magisterskie. Recenzował w przewodach doktorskich i habilitacyjnych, sporządził również wiele opinii w postępowaniach o nadanie tytułu profesora, co bez wątpienia stanowiło Jego wkład w kształcenie kadry naukowej.

Oprócz kariery naukowej Pan Profesor Banaszak był czynnym członkiem wielu instytucji, gdzie mógł wspomagać swoją wiedzą ich rozwój, nie sposób teraz je wszystkie wymienić, jednak jako najważniejsze z nich należy wskazać: przewodniczenie i członkostwo Radzie Legislacyjnej przy Radzie Ministrów, członkostwo w Grupie Niezależnych Ekspertów do spraw Europejskiej Karty Samorządu Terytorialnego Rady Europy, Europejskiej Komisji na rzecz Demokracji przez Prawo, tzw. Komisja Wenecka oraz członkiem Trybunału Stanu. Ponadto od 1992 r. stale współpracował ze służbami legislacyjnymi parlamentu oraz był autorem kilkudziesięciu ekspertyz dla naczelnych organów władz publicznych.

Za swoje zasługi otrzymał wiele odznaczeń w Polsce i za granicą, w tym między innymi: Złoty Krzyż Zasługi RP (2001 r.), Krzyż Kawalerski Orderu Odrodzenia Polski, Wielki Krzyż Zasługi Republiki Austrii, niemiecki Federalny Krzyż Zasługi na Wstędze, Austriacki Krzyż Honorowy Nauki i Sztuki I klasy, a także Order Sprawiedliwości 1-go Stopnia Światowego Stowarzyszenia Prawników. 
Ponadto Jego działalność naukowa znalazła uznanie także poza granicami naszego państwa w postaci nadania Panu Profesorowi Bogusławowi Banaszakowi tytułu Doktora honoris causa. Doceniły Go społeczności: Uniwersytetu w Pecs (Węgry - 2004 r.), Uniwersytetu w Alba Julii (Rumunia - 2009 r.), Uniwersytetu w Pitesti (Rumunia - 2010 r.) i Kijowskiego Uniwersytetu Prawa (Ukraina 2011 r.).

Profesor Bogusław Banaszak był bardzo rodzinnym człowiekiem. Zawsze miał czas dla Rodziny. To Rodzina stała zawsze na pierwszym miejscu. W dalszej kolejności była praca naukowa i organizatorska. Lubił podróże, w szczególności samochodem, a przy tym był bardzo dobrym kierowcą. Kochał wszystkie zwierzęta, te domowe pieski i kotki oraz te dzikie. Do historii przeszła już opowieść o tym jak Profesor uratował orła. Swoje psy traktował jak członków rodziny, spędzał z nimi dużo czasu, w szczególności chodząc z nimi na długie spacery w lasach okalających Jego dom.

Przyjaciele i znajomi Profesora Banaszaka zapewne zapamiętają Go jako człowieka niezmiernie ciepłego, pomocnego i uprzejmego, który nie budował barier i szybko skracał dystans. Obdarzony dużym poczuciem humoru i umiejętnością opowiadania anegdot niejednokrotnie poprawiał innym nastrój i rozładowywał napięta atmosferę. Pomagał zawsze, służąc nie tylko radą, ale także dobry słowem i uśmiechem.

Zmarł niespodziewanie 9 stycznia 2018 r. w Warszawie, pozostawiając po sobie wielką pustkę, której nie będzie możliwym zapełnić. Został pochowany na cmentarzu w Miękini.

opracowanie: Doktor Justyna Michalska

Pana Profesora Bogusława Banaszaka nie ma już pośród nas, jednak nieustannie pozostaje obecny w pamięci Swych przyjaciól, koleżanek, kolegów oraz uczniów. Wyrazem tej obecności są wspomnienia o Profesorze przygotowane przez przedstawicieli nauki prawa konstytucyjnego, osoby, które pozostawały z Nim w bliskich relacjach. Oto niektóre z nich: 


\section{Wspomnienie Profesora Andrzeja Szmyta}

Był dla mnie zawsze Bogusiem. Zbliżyła nas pasja, do której obaj przywiązywaliśmy dużą wagę - konferencje naukowe oraz aktywność publikacyjna. Obecność mą na przygotowywanych przezeń konferencjach uważał zawsze za oczywistą. Organizując grupę referentów do wystąpień na konferencje międzynarodowe nie zapomniał nigdy przewidzieć i dla mnie jakieś zadanie. Zaczęło się od cyklu spotkań we francuskim Klingenthalu, utrwaliło w cyklu kongresów w niemieckiej Ratyzbonie. Wyjazdy te rodziły dalsze kontakty naukowe, zwłaszcza w Rumunii (Alba Julia, Piteszti) oraz na Ukrainie (Kijów, Odessa), ale także Austrii, Włoszech, Mołdawii. Zawsze jednak z rolą do spełnienia. Pełen byłem uznania dla Jego sprawności, mobilności, gotowości do nowych wyzwań.

Łączyły nas wielokroć wspólne publikacje i role recenzenckie w przewodach naukowych. Z życzliwością obserwowałem, jakim źródłem siły było dla Niego szczęśliwe życie rodzinne. Jego żona Bożenka i moja Beata w sposób naturalny stały się nierozłączne przy okazji wielu wspólnych pobytów. Myślę, że w służbie publicznej chyba raczej nie miał szczęścia. Aż do jesieni przed dwoma laty zawsze konsultowaliśmy ze sobą plany, problemy. Ostatnio nie potrafiłem jednak przekonać Go do idei, by na pierwszy Jubileusz przygotowane dlań zostało dzieło zawierające wartościowe opera minora, jakże licznie przezeń wcześniej publikowane przez lata. Może nie jest na to za późno?

\section{Wspomnienie Profesora Jerzego Jaskierni}

Gdy w październiku 2017 r. uczestniczyłem w Zielonej Górze w uroczystych obchodach 40-lecia pracy naukowej Pana Prof. Bogusława Banaszaka, nie przypuszczałem, że to ostatni mój kontakt z nim. Dwa olbrzymie tomy wydane z okazji jubileuszu odzwierciedlały skalę uznania, jakim Profesor cieszył się w środowisku polskich i zagranicznych konstytucjonalistów. Był niewątpliwie jednym $z$ najwybitniejszych postaci nauki prawa konstytucyjnego, nie tylko w skali krajowej, ale też europejskiej, o czym świadczą liczne doktoraty honoris causa. Był tytanem pracy - podręcznik prawa konstytucyjnego, podręcznik prawa konstytucyjnego porównawczego, komentarz do konstytu- 
cji, komentarz do kodeksu wyborczego, nie mówiąc już o setkach opracowań w języku polskim, ale też w językach obcych. Te prace obcojęzyczne powodowały, że B. Banaszak był jednym z najbardziej rozpoznawalnych za granicą polskich konstytucjonalistów, chętnie zapraszanym na międzynarodowe konferencje.

Zawsze stawiałem sobie pytanie, jak doskonały warsztat naukowy trzeba mieć, jaką erudycję posiadać i jaką pracowitość reprezentować, by tworzyć poważne dzieła naukowe w takim tempie. Zarazem B. Banaszak był oszczędny w słowach. Obserwowałem go podczas kolokwium habilitacyjnego Konrada Składowskiego w Łodzi i podczas obrony doktoratu Jana Plisa w Olsztynie. Jego wygłoszone recenzje sprowadzały się do kilkunastu generalnych zdań. Był konkretny, nie chciał tracić czasu na zbędne gadulstwo.

Nasze drogi zawodowe spłatały się wielokrotnie. Zapamiętałem zwłaszcza konferencję w Chlewiskach, którą organizował przed laty. Poznałem wówczas Jego przyjaciól, profesorów z Austrii: Herberta Schambecka i Heriberta Koecka, którzy później wielokrotnie uczestniczyli w organizowanych przeze mnie w Sejmie międzynarodowych konferencjach dotyczących systemów ochrony praw człowieka.

Opowiadał mi, że gdy przed kilku laty zdecydował się przenieść swoją aktywność naukową do Zielonej Góry, tworząc tamtejszy Wydział Prawa i Administracji, żona zapytała go: „Czy wypada, by tak ważny profesor był zaledwie w Zielonej Górze?”, odpowiedział: „Skoro Jurek Jaskiernia może być w Kielcach, to dlaczego ja nie mógłbym być w Zielonej Górze?”.

Choć od jubileuszu upłynęło kilka miesięcy, niespodziewanie u progu 2018 r. B. Banaszak zaczął mi przesyłać mailowo zdjęcia z tych obchodów. Ostatnie przyszło 3 stycznia 2018 r. Na nim jubilat z małżonką w rozmowie ze mną, zapatrzony w przyszłość i pełen nadziei. Nie wiedziałem wówczas, że było to pożegnanie. Odszedł w pełni sił twórczych. Tyle jeszcze mógł zrobić!

\section{Wspomnienie Profesora Dariusza Góreckiego}

Właściwie nie mogę sobie przypomnieć kiedy poznałem Profesora Bogusława Banaszaka. Najprawdopodobniej było to na którymś ze zjazdów Katedr i Za- 
kładów Prawa Konstytucyjnego. W każdym razie nasze rodziny dość dawno się zaprzyjaźniły. Spotykaliśmy się nie tylko na Zjazdach Katedr i przy obronach prac doktorskich, ale także na innych konferencjach. Wdzięczny $\mathrm{Mu}$ jestem, że wspólnie z prof. Mariuszem Jabłońskim napisał referat pt: Prawo do repatriacji na zorganizowaną przeze mnie konferencję międzynarodową pod patronatem Marszałka Senatu Sytuacja ludności polskiej na Wschodzie w świetle obowiązującego prawa i praktyki (Łódź 2009). Referat spotkał się z żywym zainteresowaniem słuchaczy, zwłaszcza wśród działaczy polskich organizacji z Białorusi, Litwy, Łotwy i Rosji.

Profesor Banaszak żył szybko. Jakby spieszył się, że może nie zdążyć... Był Autorem ponad 300 znakomitych prac naukowych, doktorem honoris causa czterech zagranicznych uniwersytetów, członkiem wielu towarzystw naukowych (krajowych i zagranicznych), stowarzyszeń, ważnych instytucji państwowych oraz kolegiów redakcyjnych. Był także wieloletnim kierownikiem Katedry Prawa Konstytucyjnego Uniwersytetu Wrocławskiego, a później Uniwersytetu Zielonogórskiego i Dziekanem tamtejszego Wydziału Prawa i Administracji. Wszystkie te funkcje świadczą o jego niewątpliwym autorytecie naukowym i dużym talencie organizacyjnym. Uczestniczył w wielu międzynarodowych i krajowych konferencjach naukowych. Ostatnio podjął się trudnego zadania organizowania corocznych ogólnopolskich konferencji naukowych pt.: Zielonogórskie spotkania konstytucjonalistów. Niestety do tej pory odbyły się tylko dwie...

Z Bogusławem byliśmy w stałym kontakcie internetowym - bardzo często przysyłał mi żartobliwe filmiki, swoje publikacje i wypowiedzi w mediach oraz ciekawe fotografie, także obrazów autorstwa Jego żony Bożeny i zdjęcia swoich wnucząt, z których był taki dumny. Niestety dziś moja poczta e-mailowa nie jest już tak interesująca. Nie dawno prosił mnie, abym postarał się dla niego o książkę Powoływanie sędziów konstytucyjnych w wybranych państwach europejskich. Niestety nakład był już wyczerpany. Zrobiono dodruk i książkę wysłano. Nie wiem tylko, czy zdążył ją otrzymać...

Cechą czasu jest to, że wydaje się nam, że go ciągle mamy jeszcze dużo, że jeszcze zdążymy. A on ucieka... Niespodziewana śmierć Profesora Bogusława Banaszaka jest ogromną stratą dla kochającej Go Rodziny, dla nauki polskiego prawa konstytucyjnego, a także dla grona Jego przyjaciół i kolegów. Drogi Przyjacielu - odpoczywaj w pokoju. 


\section{Wspomnienie Profesor Haliny Zięby-Załuckiej}

Wiadomość o śmierci Pana Profesora Bogusława Banaszaka gruchnęła na nas niczym grom z jasnego nieba. Pierwszą reakcją było otępienie i niedowierzanie, dopiero później przyszedł czas na refleksję. Uświadomiliśmy sobie, jak wielką stratą jest to wstrząsające wydarzenie nie tylko dla rodziny i przyjaciół, ale także dla naszego środowiska naukowego. Pustki, jaką ono za sobą niesie, nic nie wypełni...

Odszedł od nas człowiek, o którym bez wahania powiedzieć można, że był jednym z najwybitniejszych przedstawicieli polskiej doktryny prawa konstytucyjnego. W naszej pamięci pozostaną Jego liczne publikacje naukowe oraz wykłady, będące już dziś trwałym i niezmazywalnym element polskiej myśli konstytucyjnej. Dzięki nim, my konstytucjonaliści, możemy się czuć w jakiejś mierze uczniami Pana Profesora.

Jednak przede wszystkim odszedł od nas człowiek wielkiej uczciwości i wrażliwości serca, zawsze okazujący życzliwość oraz otwartość w relacjach międzyludzkich. Nigdy nie zapomnimy tego pełnego dobra uśmiechu malującego się nieustannie na twarzy Pana Profesora, który zdradzał gotowość do niesienia pomocy kolegom, współpracownikom oraz studentom.

Mnie udało się jeszcze porozmawiać z Panem Profesorem na konferencji w Katowicach 19-20 października 2017 r., którą organizowała Pani Profesor Anna Łabno. Jak zawsze pogodny, a jako że na uroczystej kolacji miałam zaszczyt siedzieć z Nim przy wspólnym stoliku, to była okazja cieszyć się razem $\mathrm{z}$ innymi z Jego anegdot ze swoich licznych podróży. Podziwiałam też Jego talenty lingwistyczne (był tłumaczem kilku gości zagranicznych z różnych językowo krajów). Skąd mogłam przypuszczać, że będzie to moje ostatnie spotkanie z Bogusławem.

Profesor Banaszak żył między nami, z nami, ale nigdy obok nas. Wszystko co robił wypływało z naukowej pasji, ale też z chęci służenia innym ludziom. Przedwczesna śmierć przerwała Jego imponującą karierę, a nas wszystkich pozbawiła intelektualnego autorytetu i wspaniałego kolegi. Z bólem żegnamy człowieka, który miał przed sobą jeszcze tak wiele do zrobienia. 


\section{Wspomnienie Profesora Stanisława Bożyka}

Nagła śmierć Profesora Bogusława Banaszaka była chyba dla wszystkich ogromnym zaskoczeniem. Jego odejście to poważna strata dla nauki polskiego prawa konstytucyjnego, tym bardziej, że Profesor zmarł w okresie, kiedy był jeszcze bardzo aktywny naukowo oraz organizacyjnie, tworząc Wydział Prawa i Administracji Uniwersytetu Zielonogórskiego, potem zaś kierując jako Dziekan - jego działalnością.

Profesor B. Banaszak kojarzył mi się jednak zawsze z Uniwersytetem Wrocławskim, gdzie przeszedł wszystkie szczeble kariery naukowej. Poznałem Go podczas Zjazdu Katedr Prawa Konstytucyjnego zorganizowanego właśnie przez wrocławską Katedrę, który odbył się w początkach czerwca 1983 r. w Karpaczu. Dokładnie zaś po tradycyjnym piątkowym bankiecie, gdy w gronie kilkunastu młodych konstytucjonalistów (dziś już bardzo zacnych profesorów) wybrałem się na bardzo długi nocny spacer ulicami tego karkonoskiego kurortu. Bogusław Banaszak był wówczas jeszcze asystentem i przygotowywał rozprawę doktorską o cechach ustrojowych państw socjalistycznych w Azji. W mojej pamięci utkwiły szczególnie Jego niezwykle barwne opowieści o systemie rządów w Korei Północnej oraz o koncepcjach ustrojowych ówczesnego przywódcy tego państwa Kim Ir Sena.

Niemal trzydzieści lat później poprosiłem Profesora B. Banaszaka o wygłoszenie referatu podczas organizowanego przeze mnie Zjazdu Katedr Prawa Konstytucyjnego w Augustowie (10-12 maja 2012 r.). Z radością przyjął moją propozycję, ale pod warunkiem, że w pierwszym dniu obrad zagwarantuję odbiór Go z lotniska na Okęciu (Profesor wracał bodajże z Monachium) i przywiezienie do Augustowa. Tego zadania podjął się mój doktorant i wywiązał się z niego bez zarzutu. Dzięki temu Profesor zdążył jeszcze na popołudniowe zebranie kierowników Katedr, natomiast następnego dnia wygłosił bardzo interesujący referat na temat Jakie zmiany w Konstytucji RP sa potrzebne? Już po zakończeniu obrad odbyłem długą rozmowę z Profesorem, nie przewidując bynajmniej, że będzie to jedno z ostatnich Naszych spotkań. 


\section{Wspomnienie Profesora Krzysztofa Skotnickiego}

Poznaliśmy się na przełomie lat 70. i 80. ubiegłego wieku podczas jednego ze Zjazdów Katedr i Zakładów Prawa Konstytucyjnego. Dzisiaj już nie pamiętam, kiedy to było dokładnie. Czas zatarł ten moment. Było to jednak na tyle dawno, że mogę powiedzieć, iż znaliśmy się prawie od początku naszej pracy uniwersyteckiej. Początkowo nie była to też znajomość bliska, byliśmy zaledwie kolegami z różnych uniwersytetów. Powoli ulegało to jednak zmianie. Serdeczne przyjacielskie więzi to dopiero ostatnich kilkanaście, może dwadzieścia lat. Trudno też powiedzieć, jak do tego doszło. Bez wątpienia jest to w dużej mierze kwestia pokoleniowa. Ale bardziej zadecydowały o tym cechy Bogusia, jego otwartość na innych ludzi, poczucie humoru. Nie bez znaczenia były też kwestie zawodowe, takie jak częściowo zbliżone zainteresowania naukowe, przygotowywanie różnych recenzji czy opinii. Był też osobą, na którą można było liczyć, że wywiąże się ze swojego zadania szybko.

Niewątpliwie najwięcej wspomnień związanych jest ze wspólnym udziałem w konferencjach, w tym również zagranicznych. W wielu towarzyszyły nam nasze żony, które również bardzo szybko się zaprzyjaźniły. I to Bożenka, żona Bogusia, dzwoniąc wcześnie rano do mojej żony, jako jednym z pierwszych przekazała tę bardzo smutną wiadomość o Jego śmierci. W mojej pamięci chyba najwyraźniej utrwalił się wyjazd do Austrii, gdy w Linzu odbyło się jedno z wielu inspirowanych przez prof. Bogusława Banaszaka spotkań konstytucjonalistów z Austrii, Polski, Rumunii i Węgier.

Ze wspólnym wyjazdem związana jest też historia, którą chciałbym przywołać w tym wspomnieniu. Boguś bardzo lubił kakao i musiał je codziennie wypić. Nazywał je pieszczotliwie „kakaukiem”. I bardzo denerwował się, jeżeli w hotelu w Polsce lub gdzieś w świecie nie mógł się go napić podczas śniadania. Uważał, że powinno się taki hotel pozbawić jednej gwiazdki. Przywoływał też swoją przygodę z brakiem tego napoju w hotelu w Izraelu, gdy z uwagi na szabas nie bardzo miał kto dokonać zakupu kakao w sklepie. I z kim będziemy teraz podczas konferencji pić rano kakao? 


\section{Wspomnienie Profesora Mariusza Jabłońskiego}

Pamiętam jak w 1995 r. profesor Kazimierz Działocha uznał, że najlepiej dla mnie będzie jak opiekę naukową roztoczy nad moją skromną osobą Boguś Banaszak. Pamiętam też, że dość mocno się wtedy wystraszyłem. Przede wszystkim dlatego, że Bogusia identyfikowałem jedynie z bardzo wymagającym egzaminatorem, nie wiedziałem natomiast nic na temat tego, jakim jest człowiekiem. Bardzo szybko przekonałem się, że moje obawy były zupełnie bezpodstawne. Boguś okazał się bowiem nie tylko bardzo dobrym człowiekiem, ale - co było bardzo istotne z zawodowego punktu widzenia - życzliwym Mentorem, który zawsze starał się motywować mnie do pracy. Jednocześnie jako Mentor nigdy nie starał się narzucać „jedynie słusznej” drogi lub wyznaczać zagadnienia naukowego, które byłoby dla mnie „najlepsze”.

Od samego początku naszej współpracy, a potem koleżeństwa Boguś tłumaczył mi, że najważniejsze jest, żeby samodzielnie „rozpracować” problem, zmierzyć się z istniejącym dorobkiem nauki i praktyki, a ostatecznie wypracowane stanowisko, merytorycznie uzasadnić. Skutkiem Jego nauk było to, że często nasze analizy były rozbieżne, podobnie jak ocena konkretnych rozwiązań ustrojowych oraz prawnych. Nigdy jednak ujawniające się w trakcie dyskusji różnice nie prowadziły do kłótni. Wręcz przeciwnie Boguś udowadniał Swoją postawą, że można uszanować zdanie młodszego kolegi i to także wtedy, gdy kolega ten znajdował się na początku kariery naukowej.

Boguś nigdy nie odmawiał pomocy i to nie tylko w odniesieniu do doskonalenia warsztatu naukowego wielu osób, z którymi współpracował. Pomagał w swym życiu wielu osobom nie związanym ze środowiskiem prawa konstytucyjnego, robiąc to zupełnie bezinteresownie.

Kierując kilkanaście lat Katedrą Prawa Konstytucyjnego na Wydziale Prawa, Administracji i Ekonomii Uniwersytetu Wrocławskiego zawsze w pełni aprobował nowe inicjatywy naukowe oraz organizacyjne i ze wszystkich sił starał się doprowadzić do ich pomyślnego zakończenia. Zawsze imponował prostotą podejmowania decyzji, których efektem było racjonalne i skuteczne rozstrzyganie nawet najbardziej złożonych problemów.

Inną cechą Bogusia było te, że zawsze miał jakieś plany. Nie chodzi tu wyłącznie o plany naukowe, choć w tym zakresie był tytanem pracy; nie chodzi również o udział w konferencjach, opieką nad doktorantami, czy rozwo- 
jem współpracy międzynarodowej. Chodzi o plany na życie. Boguś z całego serca kochał Swoją Rodzinę i zawsze to podkreślał. Pamiętam, że podróżując wspólnie do Frankfurtu nad Odrą wielokrotnie i powtarzalnie, mówił o Swojej Małżonce i Córce, a potem Zięciu (wtedy jeszcze nie miał wnuków). Uczył mnie, że najważniejsze jest „ułożenie” pracy zawodowej tak, aby służyła życiu z Rodziną, a nie obok Niej. Ona - Rodzina - była u Bogusia na pierwszym miejscu. Mówił, że gdyby kiedykolwiek miał wybierać, to bez cienia żalu porzuciłby pracę zawodową i zajął się swoimi bliskimi.

Boguś mówił mi, że nigdy nie będzie pracował dłużej niż do 65 roku życia. Wtedy, jak stanowczo twierdził, przejdzie na emeryturę i będzie przez najbliższe - co najmniej 30 lat - zajmował się Swoimi wnukami, a potem prawnukami oraz innymi - bliżej niezdefiniowanymi - przyjemnościami. Jak Go znałem - i tak by jeszcze obok tego pisał, choć, czy byłyby to rozważania na temat prawa konstytucyjnego, nie jestem w stanie odpowiedzieć.

Na temat Jego „emerytury” rozmawialiśmy jeszcze pod koniec grudnia 2017 r. Jeszcze 3 stycznia 2018 r. Boguś przesłał mi mailem swoje zdjęcia... Kilka dni potem okazało się, że Odszedł..., nie realizując do końca Swojego planu na życie.

Brakuje mi Jego prostego spojrzenia na życie i wiecznego optymizmu.

\section{Wspomnienie Profesora Zbigniewa Maciąga}

Tak niedawno jeszcze obchodziliśmy uroczyście Jubileusz 40-lecia pracy naukowej Profesora Bogusława Banaszaka. Podkreślaliśmy jego ogromne osiągnięcia zarówno w sferze nauki, dydaktyki jak i praktycznego organizowania i rozwijania struktur im służących. Jego nadzwyczajna aktywność w intensyfikowaniu współpracy z uczelniami zagranicznymi wielu państw wzbudzała podziw i uznanie. Również na wysokim poziomie świadczona pomoc prawna jakiej udzielał organom państwa takim jak Sejm, Senat, Rada Ministrów, Rzecznik Praw Obywatelskich czy Rzecznik Praw Dziecka służyła państwu polskiemu. Nagła jego śmierć wstrząsnęła środowiskiem konstytucjonalistów nie tylko w Polsce. Odszedł bowiem człowiek wybitny, który na zawsze pozostawać będzie w naszej pamięci. 
Bogusia jako kolegę poznałem na jednym ze zjazdów katedr i zakładów prawa konstytucyjnego jeszcze w latach osiemdziesiątych dwudziestego wieku. Łączyły nas zainteresowania polskim prawem konstytucyjnym na tle porównawczym z systemami ustrojowymi innych państw, a w szczególności badania nad ustrojem Republiki Federalnej Niemiec i Republiki Austrii. W latach późniejszych wymienialiśmy się doświadczeniami z prowadzonych w RFN i Austrii wykładów i seminariów. W okresie gdy pełnił funkcję Przewodniczącego Rady Legislacyjnej (2006-2010) spotykaliśmy się w Warszawie, gdzie wymienialiśmy poglądy w kwestiach konstytucyjno-prawnych. Boguś był zwolennikiem wprowadzenia licznych zmian do obowiązującej Konstytucji z 1997r., na których konieczność jego zdaniem wskazywało wielu autorów w nauce prawa i politologii. Dotyczyć one miały jak stwierdzał regulacji związanych z członkostwem Polski w Unii Europejskiej, zwłaszcza relacji między prawem UE a Konstytucją RP i prawem polskim, współdziałania organów władzy wykonawczej i ustawodawczej w sprawach Unii, doprecyzowania ogólnej zasady demokratycznego państwa prawnego, konstytucjonalizacji elementów społeczeństwa obywatelskiego, postanowień Konstytucji dotyczących praw i wolności jednostki, zwłaszcza ich poszerzenia i ochrony w tym także modyfikacji instytucji skargi konstytucyjnej, a ponadto konstytucjonalizację prokuratury, konsolidację urzędu Rzecznika Praw Obywatelskich, likwidację sądów wojskowych. Te propozycje konstytucyjnych zmian sformułował w artykule zatytułowanym Jakie zmiany w Konstytucji RP sq potrzebne? opublikowanym w pracy pod redakcją Stanisława Bożyka, Aktualne problemy reform konstytucyjnych, Temida 2, Białystok 2013, s. 17-40. Ja natomiast uważałem, że tak daleko idące zmiany Konstytucji nie są potrzebne. Boguś zaś skłonny był nawet poprzeć dążenia do zmiany całej Konstytucji i uchwalenia zupełnie nowej, z czym ja zgodzić się nie mogłem.

Pomimo tych różnic poglądów w tak ważnych kwestiach konstytucyjnych pozostawaliśmy w bliskich kontaktach i przyjaźni. Podczas uroczystości mojego Jubileuszu 70-lecia urodzin i 45-lecia pracy naukowej w 2014 r. wygłosił piękną Laudację, która przyczyniła się do pełniejszej prezentacji moich osiągnięć. Dowodziło to jego otwartości i wspaniałomyślności. Dziś Jego brak, tak wczesne odejście, to ogromna strata dla polskiej nauki którą wszyscy boleśnie odczuwamy. 


\section{Wspomnienie Profesora Radosława Grabowskiego}

Rok 1998, może 1999. Ja, młody asystent, miałem się spotkać z Profesorem Bogusławem Banaszakiem i zasięgnąć porady w sprawie tematyki doktoratu, którego nazwisko widzę na wszystkich moich ulubionych opracowaniach naukowych. Wielka trema i równie wielkie pozytywne zaskoczenie - profesor okazuje się być człowiekiem sympatycznym, życzliwym i pomocnym. Od tej pory każda konferencja jest okazją nie tylko do rozmów naukowych, ale także - a może przede wszystkim - miłej pogawędki na tematy wszelkie. Bogusław (mistrz skracania dystansu) okazał się być miłośnikiem zwierząt, i odtąd tematyka psów, orłów, a nawet ślimaków towarzyszy naszym spotkaniom oraz korespondencji. Zawodowo łączyło nas coraz więcej: Recenzent mojej rozprawy doktorskiej, Autor tekstów w tych samych książkach, Recenzent w postępowaniu habilitacyjnym. Co szczególnie miłe, zawsze gościnny gospodarz podczas wizyt we Wrocławiu, gotów walczyć, żeby czekało miejsce w wydziałowych pokojach gościnnych z Wieżą Astronomów za oknem. Do Zielonej Góry było już nieco dalej, ale życie naukowe nadal pozwalało na spotkania przy różnych okazjach. Jednakże niespodziewania śmierć, która przyszła za szybko, zakończyła wszystko. Już nie siądziemy razem, aby opowiedzieć co nam myśli zajmuje. Niestety.. już za późno.

\section{Wspomnienie Profesor Aldony Domańskiej}

Pan Profesor Bogusław Banaszak był wybitnym znawcą prawa konstytucyjnego. Można wspominać jego rozliczne publikacje, gdyż bez wątpienia był tytanem pracy. Ale był to przede wszystkim życzliwy, pogodny i towarzyski człowiek. Z Jego nazwiskiem spotkałam się już podczas studiów. Potem widywałam Pana Profesora wielokrotnie podczas konferencji, seminariów i corocznych Zjazdów Katedr Prawa Konstytucyjnego, ale pierwsze spotkanie na zawsze pozostanie w mej pamięci. Był to dzień obrony mojej pracy doktorskiej. Czas oczekiwania na recenzje był, jak dla każdego doktoranta, pełen obaw. Jednak recenzja nadeszła bardzo szybko, a lektura jej była dla mnie bardzo satysfakcjonująca. Po kilku miesią- 
cach naszedł dzień obrony. Naturalny, w mojej ocenie, dystans doktoranta w stosunku do Profesora-Recenzenta wzmagał dodatkowo i tak towarzyszącą okolicznościom tremę. Szybko przekonałam się, że Pan Profesor to bardzo przyjazny, o ujmującej osobowości człowiek. Wrażenie z tamtego dnia pozostało do dziś.

Pamiętam Pana Profesora zarówno jako twórcę licznych publikacji, referenta podczas konferencji oraz autora inspirujących wystąpień w trakcie dyskusji. W mej pamięci Pan Prof. Bogusław Banaszak pozostanie bez wątpienia jako wybitny konstytucjonalista, ale przed wszystkim jako życzliwy, dowcipny, ujmujący w bezpośrednich kontraktach i przyjazny Człowiek.

\section{Wspomnienie Profesor Sabiny Grabowskiej}

Profesor Bogusław Banaszak żył szybko. Zawsze się śpieszył, coś miał do zrobienia. Był tytanem pracy. Ale w tym natłoku zajęć potrafił znaleźć czas, aby po prostu porozmawiać. Umiał cieszyć się z małych, jak i dużych osiągnięć.

Pamiętam, jak siedzieliśmy w Jego gabinecie na Wydziale Prawa, Administracji i Ekonomii Uniwersytetu Wrocławskiego. Profesor właśnie wrócił ze Stanów Zjednoczonych, gdzie badał funkcjonowanie komisji śledczych. Szczęśliwym zrządzeniem losu mój kolega Jim Satterwhite mógł pomóc Bogusiowi w tych badaniach. I tak się stało, że choć osobom postronnym nie wolno uczestniczyć w posiedzeniach komisji śledczych w USA, to Jimowi udało się jakoś „przemycić” Profesora na salę obrad. Po amerykańskich wojażach Profesora siedzieliśmy w gabinecie, a On z przejęciem opowiadał o tym wszystkim. Urzekło mnie to, że po tylu latach pracy jako naukowiec, nadal cieszyło Go poszerzanie wiedzy, że ciągle szukał nowych tematów badawczych i jeśli coś udało się zdobyć, dowiedzieć, to cieszył się jakby było to Jego pierwsze osiągnięcie, a nie kolejne, jedno z wielu. Bo osiągnięć miał multum. I publikacje, i nagrody, i całe grono wychowanków.

Będzie mi brakowało tego wszystkiego. Tak szybko jak żył, tak szybko odszedł. Za szybko... Po drodze pomiędzy jednym zadaniem a drugim... 


\section{Wspomnienie Profesora Jarosława Szymanka}

Profesor Bogusław Banaszak dla wszystkich osób z mojego pokolenie był postacią dobrze znaną, szczególną, wręcz - chciałoby się powiedzieć - kultową. Dla każdego, kto studiował zagadnienia prawa konstytucyjnego czy ustrojów państwowych, był On bardzo dobrze rozpoznawalnym Autorem, którego rozliczne teksty studiowało się, chociażby przygotowując do zajęć, czy później egzaminów. Napisane przez Niego, wespół z Arturem Preisnerem, Wprowadzenie do prawa konstytucyjnego (Wrocław 1993) było pozycją wręcz obowiązkową, do której wracało się długo jeszcze po skończeniu studiów. W dość oszczędnej formie, ale $\mathrm{z}$ dużą dozą wątków teoretycznych i porównawczych, stanowiło ono znakomity punkt wyjścia, szczególnie dla tych badaczy problematyki ustrojowej, którzy zorientowani byli na analizy komparatystyczne. Oczywiście Profesor Bogusław Banaszak był dobrze znany i czytany również z licznych swoich tekstów przyczynkarskich publikowanych przede wszystkim na łamach „Państwa i Prawa”, „Przeglądu Sejmowego” czy wrocławskiego „Przeglądu Prawa i Administracji”, podejmując wiele rozmaitych wątków z zakresu polskiego i porównawczego prawa konstytucyjnego.

Dla mnie osobiście prace Profesora stały się ważnym materiałem, kiedy przygotowywałem rozprawę doktorską. Pośród polskich badaczy był On bowiem jednym z tych Autorów, którzy mieli najwięcej do powiedzenia odnośnie problematyki dwuizbowości. Jego rozliczne, ważne i interesujące teksty dotyczące tej tematyki były istotną częścią obszernej bibliografii mojej dysertacji doktorskiej poświęconej dwuizbowości w europejskich państwach unitarnych. Wystarczy przywołać do dziś aktualny tekst Profesora pt. Czy Polsce potrzebna jest druga izba?, („Przeglądu Sejmowego” 1994, nr 2), albo Rola Senatu w procesie legislacyjnym, („Przegląd Sejmowy” 1999, nr 5). Jednak kopalnią wiedzy o problematyce dwuizbowości, a obok tego o większości kwestii konstytucyjnych, stał się dla nas wszystkich znakomity wręcz podręcznik Profesora Bogusława Banaszaka pt. Prawo konstytucyjne, (Warszawa 1999). Szybko podręcznik ten, mający kilka kolejnych wydań, stał się lekturą obowiązkową. Tak samo stało się zresztą z następnym wielkim dziełem Profesora, jakim był Jego pionierski w skali kraju i wyśmienity podręcznik pt. Porównawcze prawo konstytucyjne wspótczesnych państw demokratycznych, (Kraków 2004). Podręcznik ten do dnia dzisiejszego, w licznych jego następnych wy- 
daniach, jest pozycją numer jeden jeśli idzie o takie przedmioty jak „prawo konstytucyjne porównawcze” na studiach prawniczych czy „współczesne systemy polityczne" na studiach politologicznych. Do katalogu obowiązkowych lektur autorstwa Profesora Bogusława Banaszaka w krótkim czasie doszły następne, bardzo obszerne pozycje książkowe. Mam tu na myśli przede wszystkim Jego Konstytucję Rzeczypospolitej Polskiej. Komentarz, (Warszawa 2009) oraz Kodeks wyborczy. Komentarz, (Warszawa 2014).

Z czasem, kiedy sam stałem się osobą podejmującą naukowe próby analizy ustroju państwowego kontakt z Profesorem przybrał postać osobistą. Spotkaliśmy się pierwszy raz na Ogólnopolskim Zjeździe Katedr i Zakładów Prawa Konstytucyjnego, bodajże w Wierzbie w 2004 r., i od tego czasu utrzymywaliśmy stałe kontakty, choć nie były one zbyt intensywne. Zawsze jednak nasze spotkania wywoływały krótszą czy dłuższą dyskusję.

Zbliżyliśmy się z Profesorem, kiedy obaj pracowaliśmy w ramach zespołu powołanego przez Marszałka Sejmu do spraw problematyki Trybunału Konstytucyjnego (wiosną 2016 r.). Wtedy to moje rozmowy z Profesorem Bogusławem Banaszakiem stały się głębsze, poważniejsze, wielowątkowe. Kilka razy prowadziliśmy cięte dyskusje. Pamiętam jak kiedyś zaliczyliśmy się spierać, potem przekonywać do alternatywnych rozwiązań, które każdy z nas proponował. Uderzyło mnie wówczas, że Profesor był niezwykle otwarty na rozmówcę, że potrafił przyjąć jego argumentację, ale zarazem nie tracił nadziei na to, że i Jego argumenty spotkają się przynajmniej ze zrozumieniem. Przy okazji prac w zespole zobaczyłem też - wbrew temu co się niekiedy Profesorowi przypisywało - że był On szczerze zatroskany rozwojem wypadków konstytucyjnych. Zawał On sobie sprawę z tego, że Trybunał Konstytucyjnych skrojony w najogólniejszym kształcie w latach 80-tych XX w. wymaga korekty, że rozwój państwa poszedł tak dalece, że karze weryfikować konstrukcje klasyczne, chociażby te dotyczące podziału władzy czy właśnie ulokowania sądownictwa konstytucyjnego. Trafnie zaznaczał jednocześnie Profesor Bogusław Banaszak, że w dobrze zaprojektowanym ustroju każda władza powinna patrzeć wszystkim pozostałym na ręce. Sednem podziału nie jest bowiem bynajmniej proste odseparowanie jednej z nich od pozostałych w imię źle pojętej odrębności, niezależności czy niezawisłości. Podział władzy przewiduje bowiem odrębność i jakieś jądro kompetencji właściwych dla każdej $\mathrm{z}$ nich ale również, jeśli nie przede wszystkim, zinstytucjonalizowany system 
nieufności, który umożliwia patrzeć na to, co robi każda $\mathrm{z}$ władz i, w razie konieczności, zastosować właściwe rozwiązanie korekcyjne. Tak pojmowany podział władzy ma przeciwdziałać wszelkim możliwym patologiom władzy, jej oderwaniu czy np. nadmiernej atomizacji, która zawsze jest zjawiskiem niekorzystnym, zaburzającym balans instytucjonalny, który stanowi istotę każdego podziału władzy. W tym punkcie widać było tożsamość naszych poglądów. Obaj z Profesorem nie byliśmy zwolennikami fetyszyzmu konstytucyjnego, a w jego ramach kultywowania rozwiązań nawet złych czy też tych, które trącą przysłowiową myszką. Profesor Bogusław Banaszak, z czym nie sposób się nie zgodzić, uznawał, że prawo konstytucyjne nie jest skostniałą, dogmatyczną dyscypliną, że wymaga ono zawsze nowego, świeżego spojrzenia, że należy je odczytywać w szerszym polityczno-społecznym kontekście, który konstytucję pisaną - jakby powiedział Ferdynand Lassalle - czyni konstytucją rzeczywistą, osadzoną w konkretnym układzie społeczno-politycznym. Dlatego też nie może dziwić fakt, że Profesor Bogusław Banaszak jako jeden z pierwszych konstytucjonalistów zaczął angażować się w debatę nad zmianą konstytucji (mającą głównie wymiar naukowy). Uważał On, słusznie zresztą, że nie ma konstytucji idealnej, że zmiana czasu, zmiana okoliczności wymaga jeśli już nie zmiany tekstu konstytucji, to przynajmniej zmiany interpretacji konstytucji, a już na pewno zmiany dyskusji o konstytucji. W tej dyskusji, niestety, zabraknie już głosu Prosfora Bogusława Banaszaka.

\section{Wspomnienie Profesor Viktorii Serzhanovej}

Długo zastanawiałam się, co mogę napisać w ramach wspomnień o drogim koledze Profesorze Bogusławie Banaszaku. Zrozumiałam, że trudno byłoby powiedzieć to, co czuję i myślę w kilku zdaniach, o ile w ogóle byłoby to możliwe.

Wielce Szanowny Profesorze, drogi przyjacielu! To, co nasuwa się w pierwszej chwili to ogromna, głęboka i dozgonna wdzięczność za to, że byłeś z moim życiu zawodowym i prywatnym! Dziękuję losowi, że spotkałam Cię na swojej drodze i Tobie za wszystko, co dla mnie w życiu zrobiłeś. Byłeś dla mnie nie tylko wspaniałym i bardzo szanowanym starszym kolegą, wybitnym profesorem cieszącym się ogromnym autorytetem, ale bez cienia wątpliwości także moim przyjacielem. 
Dziękuję za to, że Nim byłeś, że mogłam zawsze na Ciebie liczyć, za przychylny stosunek w sprawach zawodowych, za pomoc i wsparcie, jakie w Twojej strony doświadczyłam, gdy byłeś recenzentem w moim przewodzie habilitacyjnym, za wszystkie ciepłe słowa, które napisałeś w opinii dla mnie na stanowisko profesora, za pozytywną recenzję i życzliwe uwagi dla mojego pierwszego doktoranta i wiele jeszcze innych spraw zawodowych, których nie sposób tutaj wyliczyć.

Nade wszystko jednak dziękuje Ci za wszelkie miłe chwile, które przyszło mi spędzić z Tobą i Twoimi najbliższymi prywatnie, a które to słowa wdzięczności trudno mi wyrazić słowami. Darzyłeś wszystkich spotykanych na swojej drodze ludzi ogromną życzliwością i niosłeś pomoc wszystkim z głębi swego serca. Na zawsze pozostaniesz w moim sercu i pamięci takim radosnym, pełnym życia i pozytywnej energii, wesołym i życzliwym człowiekiem, a także nieodżałowanym przyjacielem!

Dziękuję, że byłeś! Ogromnie żałuję, że już Cie nie ma i bardzo mi Ciebie brakuję, drogi Bogusiu!

\section{Wspomnienie Doktora Tomasza Mileja}

Mam przed sobą drugie wydanie (z 2001 r.) „Prawa konstytucyjnego” pióra mojego Mistrza, Pana Profesora Bogusława Banaszaka. Książka mocna używana, zszarzała, poplamiona, gdyż zaglądam do nie nieprzerwanie do dziś. Mój biały kruk. Pan Profesor napisał tam odręcznie: "Panu Tomkowi z życzeniami oszałamiającej kariery. B. Banaszak”. I przede wszystkim z tej ogromnej bezinteresownej życzliwości Pana Profesora pamiętam, z Jego autentycznej radości z sukcesów wszystkich Jego podopiecznych i troski o nich. Był Pan Profesor nie tylko moim pierwszym przewodnikiem po świecie nauki, ale też moim arbiter elegantiae. Jak wydać bankiet, gdzie kogo posadzić przy stole, jak wygłosić toast - podpatrywałem Pana Profesora i się uczyłem. A wraz ze mną niegdysiejsza młodzież akademicka wpatrzona w Niego z błogim uśmiechem.

Zawsze jeżdżąc na nasze spotkania naukowe, głównie z Kolonii do Wrocławia, cieszyłem się na myśl o miłych wieczorach i nocnych Polaków rozmowach. Pamiętam konferencję, w której uczestniczył kolega z kraju ludzi 
nie słynących z wylewności. Posadziliśmy go między nami. Po pół godzinie po raz pierwszy usłyszałem jego głos, by następnie za sprawą Profesora Banaszaka szybko przemienił się w gawędziarza. I tak Pana Profesora wspominam, Pani Bożena i Pan Profesor i ja gdzieś z boku opowiadający jakąś rzewną historię. I uśmiech Pana Profesora „Panie Tomku, będzie dobrze!”.

\section{Wspomnienie Doktor Anny Frankiewicz-Bodynek}

Profesora Bogusława Banaszaka poznałam w 1992 r., gdy rozpoczynałam studia na Wydziale Prawa i Administracji Uniwersytetu Wrocławskiego. Był jednym z tych wykładowców, którzy pomogli początkującym adeptom prawa w zrozumieniu nowej epoki i zmieniających się realiów ustrojowo-prawnych w naszym państwie. Jako studenci mieliśmy świadomość, że idą nowe czasy, nie potrafiliśmy jednak rozróżnić, które publikacje hołdują nowym ideom, a które starym. Z pomocą przyszło nam Wprowadzenie do prawa konstytucyjnego autorstwa Profesora Banaszaka i Artura Preisnera. Dziś niewielu pamięta pierwsze wydanie z 1992 r. Była to książka wydana na szorstkim, offsetowym papierze, reprodukowana „z maszynopisu dostarczonego przez autora”. Nam otwierała oczy na to, że oprócz jedynie słusznej idei, są jeszcze inne, które mogą stanowić podstawę stosunków społecznych.

Profesor Bogusław Banaszak prowadził jedynie kilka wykładów w roku. Były one ciekawe, wygłaszane z werwą, pełne przykładów obrazujących praktykę. Najbardziej utkwił mi w pamięci wykład, na którym w ramach omawiania praw człowieka Profesor mówił o orzecznictwie dotyczącym tortur. Prawo konstytucyjne tak mnie zainteresowało, że postanowiłam zapisać się na ten przedmiot w ramach seminarium magisterskiego. Przez pierwsze pół roku prowadził je Profesor Banaszak. Pamiętam, jak patrzyliśmy na Niego z podziwem, bo mówiło się, że Profesor jest drugim w Polsce najmłodszym doktorem habilitowanym. Kiedyś podczas wygłaszania referatu na seminarium strasznie się zacięłam. Chyba dzięki temu utkwiłam Profesorowi w pamięci, bo pomimo że seminarium przeszło pod opiekę Profesora Janusza Trzcińskiego, Profesor Banaszak zapamiętał mnie. Czasem prosił, żeby nadać na poczcie uniwersyteckiej jakieś zaproszenia konferencyjne, albo coś odebrać. Wypełniałam te prośby w poczuciu wielkiej misji. Pewnego dnia Profesor Banaszak 
powiedział mi, że na Wydziale Prawa otwierane są studia doktoranckie i zaproponował, żebym na nie startowała. Była to dla mnie wspaniała perspektywa, więc spróbowałam i dostałam się. Oczywiście wybrałam studia w Katedrze Prawa Konstytucyjnego. Od tamtej pory moje kontakty z Profesorem Bogusławem Banaszakiem stały się dość częste, również z tego powodu, że był on kierownikiem studiów doktoranckich. Miałam więc możliwość obserwowania, na czym polega praca naukowca.

Profesor był energicznym człowiekiem, który ciągle organizował jakieś konferencje, wizyty zagranicznych gości. Miał rozległe kontakty naukowe, często wyjeżdżał za granicę. Pełnił wiele funkcji i stanowisk na uczelniach i w naukowych gremiach. Wydawało się, że nie potrzebuje odpoczynku. Profesor angażował mnie w spotkania $\mathrm{z}$ naukowcami z innych krajów, informował o możliwościach wyjazdów na zagraniczne stypendia. Miałam więc świetny przykład do naśladowania i czerpania inspiracji. Profesor Bogusław Banaszak był recenzentem mojego doktoratu. Pamiętam, że gdy podczas obrony mieliśmy odmienne poglądy w kwestii odpowiedzialności politycznej prezydenta, Pan Profesor powiedział: „W nauce można mieć różniące się opinie. Ważne, że doktorantka potrafi swoją sensownie uzasadnić". Gdy parę miesięcy później okazało się, że promotor mojego doktoratu nie może przyjechać na rozdanie dyplomów, było oczywiste i naturalne, że wręczy mi go Profesor Banaszak. Dziś z zadumą stwierdzam, że gdyby los nie postawił na mojej drodze Profesora, byłabym zupełnie inną osobą, o innym zawodzie, na innym stanowisku. W bardzo dużym stopniu zawdzięczam Panu Profesorowi to, kim jestem i za to jestem mu wdzięczna.

\section{Wspomnienie Doktor Justyny Michalskiej}

Szanowny Pan Profesor Bogusław Banaszak był, choć nadal tak trudno pisać o Nim w czasie przeszłym, nie tylko wybitnym naukowcem i dydaktykiem, ale przede wszystkim wspaniałym i dobrym człowiekiem. Jako dydaktyk, bardzo lubiany przez studentów, co spowodowało, że niejednokrotnie wybrany został najsympatyczniejszym wykładowcą uniwersyteckim. Znany przede wszystkim z niekonwencjonalnego prowadzenia wykładów, które przetykane były licznymi anegdotami dopasowanymi do tematyki zajęć. 
Pan Profesor był również miłośnikiem psów. Posiadał ich kilka i chadzał z nimi na długie spacery, podczas których zdarzało Mu się telefonować i prowadzić rozmowy na rozmaite tematy.

Pan Profesor znany był również z dużego poczucia humoru i posiadania w zanadrzu wielu anegdot, którymi nie tylko bawił i przywoływał wspomnienia minionych lat, ale również uczył.

Współpraca z Panem Profesorem przebiegała zawsze szybko i sprawnie. Sprawiała to przede wszystkim otwartość Pana Profesora na ludzi. Młodym naukowcom stwarzał dobre warunki rozwoju, wspierając na każdym kroku i służąc wsparciem, radą i dobrym słowem.

Szanowny Panie Profesorze, będzie nam Pana Profesora bardzo brakować, już brakuje...

\section{Wspomnienie Doktora Piotra Kapusty}

Pierwsze spotkania zawsze pozostają w pamięci. Nie inaczej było ze znajomością moją i Pana Profesora. Już po jednym wykładzie z Prawa konstytucyjnego każdy student pierwszego roku doskonale wiedział, że ma do czynienia z osobą nieprzeciętną, wybitną osobowością, która każdym wykładem przyciąga rzesze słuchaczy. Choć Pan Profesor nie był praktykiem zawsze potrafił podawać przykłady dla poparcia swoich tez. Przy tym poczucie humoru i dystans do świata sprawiały, że zajęcia z Panem Profesorem po prostu sprawiały przyjemność. Po egzaminie, na dwa kolejne lata nasze drogi rozeszły się.

Bliska współpraca z Panem Profesorem rozpoczęła się dopiero na seminarium magisterskim, które rozpocząłem w kierowanej wówczas przez Pana Profesora Katedrze Prawa Konstytucyjnego WPAiE UWr. Decyzja o wyborze seminarium była prosta. Trudniejszym było zapisanie się na listę seminarzystów. Wśród starszych kolegów krążyły historie, jakoby na seminarium mogli dostać się wyłącznie najwytrwalsi - ci, którzy potrafili ukryci w budynku Wydziału przeczekać noc, by już o godzinie 7 czekać pod gabinetem Pana Profesora. Chętnych zawsze było więcej niż dostępnych miejsc.

Zmiana sposobu zarządzania budynkiem wykluczała nocowanie w nim. Wcale nie oznaczała jednak, że kolejka nie będzie tworzyć się na długo przed jego otwarciem. Chęć uczestnictwa w seminarium prowadzonym przez Pana 
Profesora zwyciężyła. Położyłem się spać o 21, wstałem o 1 i już przed 2 w nocy byłem pod wejściem do budynku. Nie byłem sam. Numer na liście -4 . Wolnych miejsc - 5. Ostatnia osoba zapisała się o 4 . Zimna noc sprawiła, że portier z innego budynku wpuścił nas na łącznik. Już o 7 z łącznika przeszliśmy pod gabinet. To właśnie dzięki seminarium mogliśmy się lepiej poznać z Panem Profesorem. Po obronie otrzymałem zaś najpiękniejszy prezent - zaproszenie na seminarium doktoranckie, z którego skorzystałem. Z Panem Profesorem współpracowaliśmy razem już do końca, do dnia Jego śmierci - 9 stycznia $2018 \mathrm{r}$.

Szczerość, zaufanie i szacunek stanowiły fundament naszej pełnej wyzwań współpracy. Szybko otwarty i zakończony obroną dysertacji przewód doktorski oraz działalność w nowoutworzonym Wydziale Prawa i Administracji Uniwersytetu Zielonogórskiego oznaczały codzienny kontakt. Było dla mnie zaszczytem móc poznać i współpracować z Panem Profesorem. Po trzech miesiącach od śmierci Pana Profesora nadal nieskasowanym pozostaje w pamięci telefonu numer Jego telefonu. Długo jeszcze tak pozostanie...

\section{Wspomnienie Doktora Bogusława Przywory}

Pana Profesora Bogusława Banaszaka pozwałem w czasie studiów doktoranckich na jednym ze Zjazdów Katedr i Zakładów Prawa Konstytucyjnego. Choć zawsze pełnił wiele funkcji w kraju i za granicą i wykonywał wiele obowiązków to zawsze ujmował swoją postawą niebywałą energią, zdolną do „przenoszenia gór” oraz otwartością na potrzeby drugiego człowieka, niezależnie od jego pozycji społecznej i zawodowej...

Mnie najbardziej w pamięci zapadł 57 Zjazd Katedr i Zakładów Prawa Konstytucyjnego w Zielonej Górze, organizowany we wrześniu 2017 r., poświęcony aktualnym problemom prawa wyborczego. Pan Profesor Bogusław Banaszak, jako Dziekan nowego powstałego Wydziału Prawa i Administracji, współorganizował to wielkie wydarzenie naukowe nie tylko dla Zielonej Góry, ale dla całej „naukowej Polski”. To wydarzenie pokazało jak dużą wagę przywiązywał Pan Profesor do spraw nauki, a także do rozwoju młodej kardy naukowej. Ujawniło również Jego umiejętności organizacyjne i menadżerskie. Równie bezcenne w walory naukowe były późniejsze, organizowa- 
ne z inicjatywy Pana Profesora tzw. Zielonogórskie Spotkania Konstytucjonalistów, poprzez które Pan Profesor stworzył „międzynarodową platformę wymiary myśli konstytucyjnej".

I ostatnie spotkanie z Panem Profesorem w Katowicach w październiku 2017 r. Po konferencji naukowej i oficjalnej części, pomimo zmęczenia i już późnej pory Pan Profesor dołączył do grona młodych pracowników naukowych i prowadził intensywną dyskusję, tym owocniejszą, że wskazywał rady i dzielił się swoim doświadczeniem życiowym...

\section{Wspomnienie Kamili M. Bezubik}

Miałam zaszczyt i przyjemność poznać śp. Pana Profesora Bogusława Banaszaka będąc jeszcze studentką Europejskiego Uniwersytetu „Viadrina” we Frankcfurcie nad Odrą i Uniwersytetu Adama Mickiewicza w Poznaniu w ramach kierunku studiów German and Polish Law. Profesor w latach 1998-2008 kierował Katedrą Polskiego Prawa Publicznego na Wydziale Prawa „Viadriny”. Włożył wiele serca i wysiłku w pracę na rzecz polsko - niemieckiego kształcenia prawników. Bez wątpienia znacząco przyczynił się do wzrostu renomy tego uniwersytetu. Spotkałam wówczas wielu wspaniałych Profesorów, którym wiele zawdzięczam i których nigdy nie zapomnę, a jednym z nich był z pewnością śp. Profesor Bogusław Banaszak.

Zawsze byłam pod wrażeniem klarowności wykładów Profesora. Zwracała uwagę Jego wyjątkowa postawa, pełna pasji i zaangażowania w wykładany przedmiot. Był bardzo otwarty i życzliwy wobec studentów. Miało to dla nas ogromne znaczenie. Byliśmy daleko od swoich domów, w obcym kraju - każda pomocna, przychylna nam osoba stawała się bardzo bliska. Profesor cenił studentów, był ich wielkim sprzymierzeńcem. Zawsze miał dla nas czas, i co rzadkie, obdarzał nas wielkim kredytem zaufania. W mojej pamięci spotkania z Profesorem pozostaną jako to doświadczenie, które rozbudziło moje zainteresowania prawem konstytucyjnym i zamiłowanie do zawodu. Bardzo żałuję, że nie będzie już w środowisku konstytucjonalistów, prawników, Profesora, który ubogacał wszystkich mądrością, przyjaźnią i serdecznością. W świecie akademickim zabrakło świetnego uczonego, wspaniałego wykładowcy, ciepłego i prawego człowieka. 
Profesor Bogusław Banaszak odszedł z Naszego grona, nie uczynił tego jednak w sposób ostateczny i definitywny. Pozostał po Nim ogromny dorobek naukowy. To właśnie te dzieła stanowiące życiową spuściznę Profesora Banaszaka, jak również wspomnienia, które zachowaliśmy powodują, że Profesor Bogusław Banaszak na zawsze pozostanie w pamięci swych bliskich, przyjaciół, uczniów i współpracowników.

Professor, non omnes mortuus! 